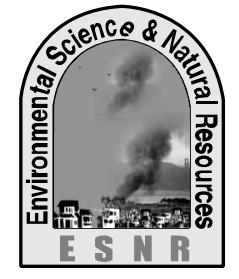

\title{
Soil Quality and Heavy Metal Concentrations in Agricultural Lands around Dyeing, Glass and Textile Industries in Tangail District of Bangladesh
}

\author{
T. R. Tusher*, A. S. Piash, M. A. Latif, M. H. Kabir and M. M. Rana \\ Department of Environmental Science and Resource Management \\ Mawlana Bhashani Science and Technology University, Tangail-1902 \\ *Corresponding author: trtusher.esrm@gmail.com
}

\begin{abstract}
The study was conducted to investigate the soil quality including heavy metal concentrations in agricultural lands around dyeing, glass and textile industries at Tangail district of Bangladesh. A total of nine samples, three samples from each industrial site, were collected at a depth of $0-15 \mathrm{~cm}$ with an interval of $10 \mathrm{~m}$ from each point of the agricultural lands adjacent to selected industries for analyzing the soil chemical properties such as $\mathrm{pH}, \mathrm{OM}$, total $\mathrm{N}$, available $\mathrm{P}$ and $\mathrm{S}$ including heavy metals $(\mathrm{Pb}, \mathrm{Cd}, \mathrm{Ni}, \mathrm{Cu}$ and $\mathrm{Cr}$ ) concentrations. The study found soil $\mathrm{pH}$ of 6.4 and 6.1 around textile and glass industry, respectively, while comparatively lower $\mathrm{pH}$ (4.4) was observed around dyeing industry. Comparatively higher levels of OM, total N, available $\mathrm{P}$ and $\mathrm{S}$ were found in soil around dyeing industry, whereas lower levels of $\mathrm{OM}$ and available $\mathrm{S}$ were observed around textile industry. $\mathrm{The} \mathrm{Cu}, \mathrm{Pb}$ and $\mathrm{Cr}$ were the dominant heavy metal around dyeing, glass and textile industry, respectively.
\end{abstract}

Keywords: Dyeing industry, Glass industry, Heavy metals, Soil properties, Textile industry

\section{Introduction}

Soils of the world have been degraded and contaminated by various anthropogenic activities that change the physical, chemical and biological properties of soil; resulting in nutrient deficiency, soil toxicity, improper soil and crop management, alteration of agricultural landsand also human and animal health hazard through the food chain ( $\mathrm{Tu}$ et al., 2000; Dahmani-Mueller et al., 2001; McGrath et al., 2002; Rahman et al., 2012; Adegoke, 2009). Industrial discharge of untreated or partially treated effluents directly into surrounding agricultural lands is considered as the most significant anthropogenic activity responsible for soil pollution by various pollutants like heavy metals such as $\mathrm{Cd}, \mathrm{Cu}, \mathrm{Zn}, \mathrm{Cr}$, $\mathrm{Ni}, \mathrm{Pb}$ and $\mathrm{Mn}$ (Islam et al., 2012; Jolly et al., 2012; Yadav et al., 2002). Agricultural crops can also be injured, ranged from visible markings on the foliage to premature death of the plants, when exposed to high concentrations of pollutants (Gheorghe and Ion, 2012).

Bangladesh has now more than 30,000 industrial units of which about 900 are large polluting industries, which discharging heavily toxic effluents directly into the adjacent soils (Nuruzzaman et al., 1998). Approximately 30 million gallons of untreated industrial waste water effluent are mixing daily with our environment mainly with water and soil
(Jolly et al., 2012). Among them, around 600-700 textile, dyeing and glass industries have been set up around Dhaka at Narayangonj, Tejgaon, Savar, Tongi, Gazipur and Tangail areas during the last few years (Khan, 2006). The contamination by heavy metals causes a serious problem and threaten to human health and problems associated with long-term heavy metal exposures causes eventually death (Rahman et al., 2012).

There are 1184 industries in Tangail from which a large amount of industrial effluents are discharged into the surrounding agricultural lands daily (BBS, 2013). As a result, the agricultural lands are losing their fertility and the crop production is decreasing. The soil quality along with the heavy metal concentrations in these agricultural lands exposed to different industrial effluents is needed to investigate to understand the extent of effects of industrial effluents of each category on agricultural soils. With this incentives the study was conducted: (i) to assess the soil properties ( $\mathrm{pH}, \mathrm{OM}$, total $\mathrm{N}$, available $\mathrm{P}$ and available $\mathrm{S}$ ) including heavy metals $(\mathrm{Pb}, \mathrm{Cd}, \mathrm{Ni}, \mathrm{Cu}, \mathrm{Cr})$ of agricultural lands adjacent to the dyeing, glass and textile industries in Tangail district; and (ii) to identify the dominant heavy metals in soil around dying, glass and textile industries. 


\section{Materials and Methods}

\section{Study area}

The study area was Tangail sadar and Mirzapur Upazilla of Tangail district which is surrounded by several districts, such as Jamalpur on the north, Dhaka and Manikganj on the south, Mymensingh and Gazipur on the east, and Sirajganj on the west. The total geographic area of the district is $3414.35 \mathrm{~km}^{2}$ and the district lies between $24^{\circ} 01 \mathrm{Nj} \mathrm{j}^{\prime}$ and $24^{\circ} 47 \mathrm{Nj} \mathrm{j} " \mathrm{~N}$ north

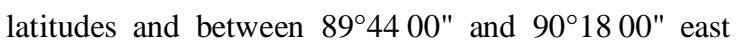
longitudes (BBS, 2013).

\section{Sample collection and preparation}

A total of nine (9) samples, three from each industrial site, were collected at a distance of $10 \mathrm{~m}$ from each point of the agricultural land in the vicinity of three different industries (Alauddin Textile Mills, Tangail; Newtex Dyeing industry, Mirzapur; Nasir Group Glass
Industry, Mirzapur). The soil samples were collected at 0-15 cm depth. The details of the soil samples collection are described in Table 1. The collected soil samples were carried to the laboratory of the Department of Environmental Science and Resource Management (ESRM), Mawlana Bhashani Science and Technology University (MBSTU), Tangail, Bangladesh, where the samples were dried in air for 10 days by spreading on a clean piece of paper, and then gravels, pebbles, plant roots, leaves, etc. were picked up and removed. The samples were then mixed well and grind to pass through a $2 \mathrm{~mm}$ mesh stainless steel sieve. The soil samples were kept in a clean polythene bag and then transported to the laboratory of Bangladesh Institute of Nuclear Agriculture (BINA), Mymensingh, Bangladesh for the analysis of soil properties including heavy metals.

Table 1. Details of soil samples with their sampling points and locations

\begin{tabular}{cccc}
\hline SL No. & Sample code & Sampling distance $(\mathbf{m})$ & Name of the industry \\
\hline 1 & DS1 & 0 & \\
2 & DS2 & 10 & Newtex Dyeing Industry \\
3 & DS3 & 20 & \\
\hline 4 & GS1 & 0 & Nasir Glass Industry \\
5 & GS2 & 10 & \\
6 & GS3 & 20 & Alauddin Textile Mills \\
\hline 7 & TS1 & 0 & \\
\hline
\end{tabular}

\section{Sample analysis}

The chemical properties of soil were analyzed by different methods such as soil $\mathrm{pH}$ by digital $\mathrm{pH}$ meter (Model: ZD5PM0909), organic matter (OM) by Walkley and Blackôs wet oxidation method (Piper, 1950), total nitrogen (N) by Semi-micro Kjeldahl method (Page et al., 1989), available sulphur (S) by Turbidimetric method (Jackson, 1973), available phosphorus (P) by Olsenôs method (Black, 1965) and the heavy metals lead $(\mathrm{Pb})$, cadmium $(\mathrm{Cd})$, nickel $(\mathrm{Ni})$, copper $(\mathrm{Cu})$ and chromium $(\mathrm{Cr})$ were analyzed by using Atomic Absorption Spectrophotometer (McLaren et al., 1984).

\section{Heavy metal contamination assessment}

The contamination factor (CF) is the ratio obtained by dividing the measured concentration of individual metal in the soil by the background value given by Turekian and Wedepohl (1961) and the CF for single metal was calculated by the following formula (Tomilson et al., 1980):
$\mathrm{CF}=$ Measured metal concentration $\left(\mathrm{C}_{\mathrm{m}}\right)$ / Background concentration of the metal $\left(\mathrm{B}_{\mathrm{m}}\right)$

The contamination degree (CD) for each point was calculated as sum of all CF (Ahdy and Khaled, 2009). Hakanson (1980) demonstrated 4 grade ratings of soil in relation to $\mathrm{CF}$ values such as low $(\mathrm{CF}<1)$, moderate (1 ÒCF <3), considerable (3 ÒCF <6), and very high (CF Ó 6). Moreover, Tomilson et al. (1980) stated 4 classes of soil depend on the CD levels, such as CD <6(low), 6 Ò CD <12(moderate), 12 Ò $\mathrm{CD}$ $<24$ (considerable), and CD Ó24(very high).

\section{Statistical analysis}

The data were finally compiled, tabulated and subjected to statistical analysis. The Microsoft Office Excel 2013 software were used for data analysis and presentation. Various descriptive statistical measures such as range, mean and standard deviation (SD) were used. 


\section{Results and Discussions}

\section{Soil pH}

The result of the study found that soil $\mathrm{pH}$ was ranged from 4.0 to 4.8 with mean value of 4.4 in the vicinity of dyeing industry, whereas soil $\mathrm{pH}$ was ranged from 5.8 to 6.4 with average value of 6.1 , and from 6.0 to 7.0 with the mean value 6.4 around the glass and textile industry, respectively (Table 2). The soil $\mathrm{pH}$ observed around glass and textile industries were within the standard value 5.5 to 7.3 by BARC (1997), while the samples around dyeing industry showed lower value from standard value. The highest $\mathrm{pH}$ (7.0) was found at TS2 around textile industry and the lowest (4.3) was at DS3 around dyeing industry (Table $2)$. Very strongly acidic soil $\mathrm{pH}(<4.5)$ was observed around dyeing industry, while slightly acidic (5.6 to 6.5) was found around both glass and textile industries. The value of $\mathrm{pH}$ decreases with the decrease of carbonate and bicarbonate (Sonawane et al., 2010) which might be the cause behind the very strong acidic soil $\mathrm{pH}$ around the dyeing industry. Shivkumar et al. (2012) reported that the $\mathrm{pH}$ range of all the soil samples in all the industrial area were in the normal range of from 6.2 to 7.9 in Mysore city of India.

Table 2. Observed soil properties of agricultural lands around different industries

\begin{tabular}{ccccccc}
\hline $\begin{array}{c}\text { SL } \\
\text { No. }\end{array}$ & $\begin{array}{c}\text { Sample } \\
\text { ID }\end{array}$ & $\begin{array}{c}\text { Soil } \\
\mathbf{p H}\end{array}$ & $\begin{array}{c}\mathbf{O M} \\
\mathbf{( \% )}\end{array}$ & $\begin{array}{c}\text { Total } \\
\mathbf{N}(\mathbf{\%})\end{array}$ & $\begin{array}{c}\text { Available } \\
\mathbf{P}(\mathbf{p p m})\end{array}$ & $\begin{array}{c}\text { Available } \\
\text { S (ppm) }\end{array}$ \\
\hline 1 & DS1 & 4.3 & 5.52 & 0.33 & 39.09 & 620.63 \\
2 & DS2 & 4.8 & 4.95 & 0.40 & 46.60 & 1993.95 \\
3 & DS3 & 4.0 & 8.87 & 0.58 & 38.01 & 1941.13 \\
Mean \pm SD & $\mathbf{4 . 4 0} \pm \mathbf{0 . 4 0}$ & $\mathbf{6 . 4 5} \pm \mathbf{2 . 1 2}$ & $\mathbf{0 . 4 4} \pm \mathbf{0 . 1 3}$ & $\mathbf{4 1 . 2 3} \pm \mathbf{4 . 6 8}$ & $\mathbf{1 5 1 8 . 5 7} \pm \mathbf{7 7 8 . 0 9}$ \\
\hline 4 & GS1 & 6.2 & 4.80 & 0.07 & 20.75 & 122.80 \\
5 & GS2 & 6.4 & 4.45 & 0.09 & 19.41 & 228.50 \\
6 & GS3 & 5.8 & 4.31 & 0.12 & 24.26 & 215.24 \\
Mean \pm SD & $\mathbf{6 . 1 0} \pm \mathbf{0 . 3 1}$ & $\mathbf{4 . 5 2} \pm \mathbf{0 . 2 5}$ & $\mathbf{0 . 1 0} \pm \mathbf{0 . 0 3}$ & $\mathbf{2 1 . 4 7} \pm \mathbf{2 . 5 0}$ & $\mathbf{1 1 8 . 8 3} \pm \mathbf{5 7 . 5 6}$ \\
\hline 7 & TS1 & 6.0 & 2.10 & 0.16 & 36.12 & 125.45 \\
8 & TS2 & 7.0 & 0.91 & 0.07 & 28.84 & 67.35 \\
9 & TS3 & 6.2 & 0.91 & 0.08 & 25.07 & 68.67 \\
Mean \pm SD & $\mathbf{6 . 4 0} \pm \mathbf{0 . 5 3}$ & $\mathbf{1 . 3 1} \pm \mathbf{0 . 6 9}$ & $\mathbf{0 . 1 0} \pm \mathbf{0 . 0 5}$ & $\mathbf{3 0 . 0 1} \pm \mathbf{5 . 6 2}$ & $\mathbf{8 7 . 1 6} \pm \mathbf{3 3 . 1 7}$
\end{tabular}

Note: DS- Dyeing industry sample, GS- Glass industry sample, TS- Textile industry sample

\section{Organic matter (OM)}

The OM content in soil was ranged from 4.95 to $8.87 \%$ around the dyeing industry, whereas 4.31 to 4.80 and 0.91 to $2.10 \%$ were observed around the textile and glass industry, respectively. The mean OM content was $6.45,4.52$ and $1.31 \%$ in soil around the dyeing, textile and glass industry, respectively. The highest OM content $(8.87 \%)$ was recorded at DS3 and the lowest $(0.91 \%)$ was at the sampling points TS2 and TS3 (Table 2). It was also observed that in case of glass and textile industries the OM content in soil decreases with increase of the distance from the industry. In case of dying industry, the irregular values are observed because effluent discharge to the agricultural land from all sides through the leakage of pipeline. The values of $\mathrm{OM}$ in soil around glass industry were within the standard value 3.00 to $5.00 \%$ set by BARC (1997), while the soil OM around dyeing and textile was found above and below the standard value. Kanta et al. (2014) stated that the high range of OM from 0.31 to
$12 \%$ in agricultural land of the Tongi industrial areas, Gazipur due to heavy organic load in the river. Strongly acidic condition in the soil is the main reason for high amount of OM because of low growth of microorganism which results in low oxidation of organic matter (Biswas and Mukherjee, 1997). Thus, it might also be the main reason of high OM content in agricultural land around dyeing industry.

\section{Total nitrogen (N)}

The study observed that the total $\mathrm{N}$ content in soil was ranged from 0.33 to $0.58 \%$ with mean value of 0.44 in the vicinity of dyeing industry, whereas the total $\mathrm{N}$ content was ranged from 0.07 to $0.12 \%$ with average value of 0.01 and from 0.08 to $0.16 \%$ with the mean value of $0.10 \%$ around the glass and textile industry, respectively. The highest content of total $\mathrm{N}$ was found at the point DS3 and the lowest content was found in GS1 and TS2. The mean value of total $\mathrm{N}$ content found in soil around dyeing industry exceeded the standard 
value $0.32 \%$ by BARC (1997), while lower value from the standard was observed in case of glass and textile industries. Ayres and Westcot (1994) stated that total $\mathrm{N}$ is a necessary primary macronutrient for plants that stimulates plant growth and is usually added as a fertilizer but can also be found in wastewater as nitrate, ammonia, organic nitrogen or nitrite. The total $\mathrm{N}$ content recorded at different sampling points around different industries of Tangail district was ranged from 0.074 to $0.583 \%$ which was similar to the total $\mathrm{N}$ contents of Gazipur sadar thana soils ranged from 0.03 to $0.47 \%$ (SRDI, 2001).

\section{Available phosphorus (P)}

The study revealed that the available $\mathrm{P}$ content was observed 38.1 to $46.6 \mathrm{ppm}$ with mean value of 42.53 ppm around the dying industry, whereas the range proximity to glass and dying industries were 19.41 to 24.26 and 24.07 to $36.12 \mathrm{ppm}$ with mean value of 21.47 and $29.68 \mathrm{ppm}$, respectively. The highest value was found at DS2 and lowest value was recorded at GS2 point (Table 2). The observed mean available $\mathrm{P}$ contents around the dyeing and textile industries were above the standard value 26.25 ppm of BARC (1997), while the lower value was recorded in soil around glass industry. Kanan et al. (2014) found that the concentration of available P was 29.84 to $30.70 \mathrm{ppm}$ in the soil around the textile industry in Narsingdi which was similar to the present study. Soil irrigated with waste water contains high amount of available $\mathrm{P}$ which play significant role in plant growth (Nidhi et al., 2011; Joshi and Santani, 2012).

\section{Available sulphur (S)}

The study revealed that level of available $\mathrm{S}$ ranged from 620.63 to $1993.95 \mathrm{ppm}$ with mean value of 1515.75 near to the dyeing industry whereas it ranged from 122.8 to $228.5 \mathrm{ppm}$ with mean value of 118.83 adjacent to the glass industry and 67.35 to $125.45 \mathrm{ppm}$ with mean value of 87.16 in the soil proximity to the textile industry. The highest content of available $S$ was found at the point of DS2 and lowest was found at the point of TS2 (Table 2). The value of available $\mathrm{S}$ concentration in all sampling points exceeded the permissible value 26.25 ppm given by BARC (1997). Strong acidic condition in soil support poor growth of microorganism. As a result, low decomposition of sulpher is responsible for high concentration of sulpher (Biswas and Mukherjee, 1997; Soni and Bhaskar, 2012). This might be the main reason of high concentration of sulpher in the soil adjacent to dyeing industry.

\section{Lead $(\mathrm{Pb})$}

The concentration of $\mathrm{Pb}$ was found 24.55 to $42.4 \mathrm{ppm}$ in soil around the dying industry with mean value of $32.5 \mathrm{ppm}$, whereas the concentration ranged from 96.5 to 167.1 and 28.2 to $29.2 \mathrm{ppm}$ around the glass and textile industry with mean value of 134.9 and 27.18 ppm, respectively. The highest concentration of $\mathrm{Pb}$ was found at GS2 and the lowest concentration was observed at TS1 (Table 3). All the values exceeded the maximum permissible level of $\mathrm{Pb}(0.1 \mathrm{ppm})$ in soil (Chiroma et al., 2014) due to continuous discharge of effluents on the surrounding lands. Vandana et al.(2011) observed the concentration of $\mathrm{Pb}$ ranging from 42.9 to $1835.0 \mathrm{ppm}$ in hazardous waste disposal site of Hyaderabad, India. Lead is used in fluxes and coloring agents in the glass industry (IFC, 2007). Uses of huge amount of $\mathrm{Pb}$ as coloring agent might be the cause of higher concentration of $\mathrm{Pb}$ in soil around the glass industry.

\section{Cadmium (Cd)}

The study investigated that the total $\mathrm{Cd}$ concentrations were ranging from 0.55 to $1.00 \mathrm{ppm}$ around dyeing industry with mean value of $0.83 \mathrm{ppm}$, whereas 1.45 to $1.60 \mathrm{ppm}$ with mean value of $1.53 \mathrm{ppm}$ and 0.75 to $2.70 \mathrm{ppm}$ with mean value of $1.4 \mathrm{ppm}$ was observed in soil around the glass and textile industry, respectively. The highest value was found at TS1 and the lowest value was found at TS1 and TS3 (Table 3). The study indicated that the all the values of $\mathrm{Cd}$ concentration exceeded the maximum permissible level of $0.01 \mathrm{ppm}$ in soil (Chiroma et al., 2014). Bharti et al. (2013) recorded that the mean concentration of $\mathrm{Cd}$ was 1.927 ppm in the soil irrigated with effluent of textile in Panipath city of India. In the study, the concentration of $\mathrm{Cd}$ was found low in comparison with other heavy metals because of low adsorptive nature of soil (Mido and Satake, 2003).

\section{Nickel (Ni)}

The investigation revealed that concentration of $\mathrm{Ni}$ ranged from 32.65 to $50.20 \mathrm{ppm}$ with mean value of 42.73 in agricultural soil adjacent to the dyeing industry whereas level was found 46.00 to $58.05 \mathrm{ppm}$ with mean value of 52.56 near to the glass industry and 37.00 to $41.75 \mathrm{ppm}$ was found near the textile industry. The highest concentration was found at GS1 and lowest was found at TS1 (Table 3) and the value of all points exceeded the standard limit 6.5 (Chiroma et al., 2014). Iqbal et al. (2011) observed the concentration of Ni ranging from 32.1 to $94 \mathrm{ppm}$ in the agricultural land irrigated with industrial effluent in Pakistan. Kanta et al. (2014) observed the concentration of $\mathrm{Ni}$ ranging from 11.11 to $80.82 \mathrm{ppm}$ in agro industrial area of 
northern part of Dhaka. Ni is used as mold alloy because of good abrasive resistance and good corrosion resistance at high temperatures in glass industry (Hoganas, 2013). That is the reason for highest concentration of Ni near glass industry.

\section{Copper $(\mathrm{Cu})$}

The study showed that the concentrations of copper $(\mathrm{Cu})$ were recorded ranging from 103.70 to 151.75 ppm in dyeing industry, 29.05 to $43.80 \mathrm{ppm}$ in glass industry and 29.55 to $79.55 \mathrm{ppm}$ in textile industry soils. The mean value of total $\mathrm{Cu}$ concentration was found 122.97, 35.93 and $47.62 \mathrm{ppm}$ around dyeing, glass and textile industry, respectively. The highest value of $\mathrm{Cu}$ was found at DS3 and the lowest value was observed at GS2 (Table 3). All the values of $\mathrm{Cu}$ concentrations exceeded the maximum permissible level of $\mathrm{Cu}(1.5 \mathrm{ppm})$ in soil (Chiroma et al., 2014). As industrial effluents contain significant amounts of $\mathrm{Cu}$ (Sharma and Raju, 2013) the continuous discharge of $\mathrm{Cu}$ containing industrial effluents might be the cause of the higher $\mathrm{Cu}$ concentrations in soil of surrounding agricultural lands. The average value of $\mathrm{Cu}$ in soil around the glass and textile industry was similar to the results reported by Zakir et al.(2015) in industrial areas.

\section{Chromium (Cr)}

The study revealed that the concentration of $\mathrm{Cr}$ ranging from 48.5 to $86.8 \mathrm{ppm}$ in the soil adjacent to the dying industry with mean value of $69.27 \mathrm{ppm}$, whereas the concentration was found 65.65 to $166.05 \mathrm{ppm}$ around the glass industry with mean value of $122.38 \mathrm{ppm}$ and 44.55 to $67.65 \mathrm{ppm}$ with mean value of $58.68 \mathrm{ppm}$ around the textile industry. The highest concentration of $\mathrm{Cr}$ was recorded at GS3 and lowest concentration was recorded at TS1 (Table 3). All the values of $\mathrm{Cr}$ concentrations exceeded the maximum permissible level of $\mathrm{Cr}$ (0.05) in soil (Chiroma et al., 2014). ElBahi et al. (2013) observed the concentration of $\mathrm{Cr}$ in the soil of Wadi El Rayan, Egypt ranging from 23-203 $\mathrm{ppm}$. The $\mathrm{Cr}$ is used as green coloring agent in form of Sodium dichromate $\left(\mathrm{Na}_{2} \mathrm{Cr}_{2} \mathrm{O}_{7}\right)$ in fluxing and production of frit (Agarwal and Varshney, 2014; IFC, 2007) which is responsible for high concentration of Cr surrounding the soil of glass industry.

Table 3. Heavy metal concentrations in agricultural lands around different industries

\begin{tabular}{|c|c|c|c|c|c|c|}
\hline $\begin{array}{l}\text { SL } \\
\text { No. }\end{array}$ & $\begin{array}{c}\text { Sample } \\
\text { ID }\end{array}$ & $\begin{array}{c}\mathbf{P b} \\
(\mathrm{ppm})\end{array}$ & $\begin{array}{c}\text { Cd } \\
(\mathbf{p p m})\end{array}$ & $\begin{array}{c}\mathrm{Ni} \\
(\mathrm{ppm})\end{array}$ & $\begin{array}{c}\mathrm{Cu} \\
(\mathrm{ppm})\end{array}$ & $\begin{array}{c}\mathrm{Cr} \\
(\mathrm{ppm})\end{array}$ \\
\hline 1 & DS1 & 24.55 & 0.55 & 32.65 & 113.40 & 48.05 \\
\hline 2 & DS2 & 30.55 & 0.95 & 45.35 & 103.70 & 72.95 \\
\hline 3 & DS3 & 42.40 & 1.00 & 50.20 & 151.75 & 86.80 \\
\hline \multicolumn{2}{|c|}{ Mean \pm SD } & $32.5 \pm 9.08$ & $0.83 \pm 0.25$ & $42.73 \pm 9.06$ & $122.95 \pm 25.1$ & $69.27 \pm 19.64$ \\
\hline 4 & GS1 & 96.50 & 1.45 & 58.05 & 43.80 & 65.65 \\
\hline 5 & GS2 & 167.10 & 1.55 & 46.00 & 29.05 & 135.45 \\
\hline 6 & GS3 & 141.10 & 1.60 & 53.65 & 34.95 & 166.05 \\
\hline \multicolumn{2}{|c|}{ Mean \pm SD } & $134.9 \pm 35.1$ & $1.53 \pm 0.08$ & $52.56 \pm 6.09$ & $35.93 \pm 7.42$ & $122.38 \pm 51.46$ \\
\hline 7 & TS1 & 28.20 & 2.70 & 28.20 & 36.12 & 44.55 \\
\hline 8 & TS2 & 24.15 & 0.75 & 37.00 & 28.84 & 63.85 \\
\hline 9 & TS3 & 29.20 & 0.75 & 41.75 & 25.07 & 67.65 \\
\hline \multicolumn{2}{|c|}{ Mean \pm SD } & $27.18 \pm 2.67$ & $1.4 \pm 1.13$ & $35.65 \pm 6.88$ & $30.01 \pm 6.88$ & $58.68 \pm 12.39$ \\
\hline
\end{tabular}

Note: DS- Dyeing industry sample, GS- Glass industry sample, TS- Textile industry sample

\section{Soil contamination assessment}

The highest CF value was found 9.0000 for Cd at TS1 among the all studied heavy metals might be due to the discharged of textile waste water in this site whereas the lowest CF value was found 0.5571 in TS3 point. The mean $\mathrm{CF}$ values of all metals were found in the following order: $\mathrm{Cd}$ (4.1851: considerable) $>\mathrm{Pb}$ (3.2375: considerable) $>\mathrm{Cu}$ (1.3991: moderate) $>\mathrm{Cr}$ (0.9271: low) > Ni (0.6418: low) and the study stated that soil of the studied industrial areas were low to considerably contaminated by heavy metals (Table 4). The maximum CD value was found 16.3485 at GS2 whereas the minimum CD (5.6018) was found at TS2. The CD values for all metals in the all points over the all sites were found higher than 6 to lower than 24 which indicated moderate to considerable level of contamination apart from the TS2 and 3, might be due to the receiving of extensive amount of municipal and industrial waste water in the study areas (Table 4). 
Table 4. Contamination factor $(\mathrm{CF})$ and contamination degree $(\mathrm{CD})$ of heavy metals for soil in the study area

\begin{tabular}{|c|c|c|c|c|c|c|c|}
\hline \multirow[t]{2}{*}{ Site } & \multirow[t]{2}{*}{ Points } & \multicolumn{5}{|c|}{ Contamination Factor (CF) } & \multirow[t]{2}{*}{ CD } \\
\hline & & $\mathbf{P b}$ & Cd & $\mathbf{N i}$ & $\mathbf{C u}$ & $\mathrm{Cr}$ & \\
\hline Newtex Dyeing & DS1 & 1.23 & 1.83 & 0.48 & 2.52 & 0.53 & 6.59 \\
\hline \multirow[t]{2}{*}{ Industry } & DS2 & 1.53 & 3.17 & 0.67 & 2.30 & 0.81 & 8.48 \\
\hline & DS3 & 2.12 & 3.33 & 0.74 & 3.37 & 0.96 & 10.53 \\
\hline \multirow[t]{3}{*}{ Nasir Glass Industry } & GS1 & 4.83 & 4.83 & 0.85 & 0.97 & 0.73 & 12.21 \\
\hline & GS2 & 8.36 & 5.17 & 0.68 & 0.65 & 1.51 & 16.35 \\
\hline & GS3 & 7.01 & 5.33 & 0.79 & 0.78 & 1.85 & 15.75 \\
\hline Alauddin Textile & TS1 & 1.41 & 9.00 & 0.41 & 0.80 & 0.50 & 12.12 \\
\hline \multirow[t]{2}{*}{ Mills } & TS2 & 1.21 & 2.50 & 0.54 & 0.64 & 0.71 & 5.60 \\
\hline & TS3 & 1.46 & 2.50 & 0.61 & 0.56 & 0.75 & 5.88 \\
\hline Minimum $\left(\mathbf{M}_{\min }\right)$ & & 1.21 & 1.83 & 0.41 & 0.56 & 0.50 & 5.60 \\
\hline $\operatorname{Maximum}\left(\mathbf{M}_{\max }\right)$ & & 8.36 & 9.00 & 0.85 & 3.37 & 1.85 & 16.35 \\
\hline Mean & & 3.24 & 4.18 & 0.64 & 1.40 & 0.93 & 10.39 \\
\hline
\end{tabular}

\section{Conclusion}

The study observed that very strong acidic soil and highest $\mathrm{OM}$, total $\mathrm{N}$, available $\mathrm{P}$ and $\mathrm{S}$ were found around dyeing industry whereas the lowest $\mathrm{OM}, \mathrm{N}$ and $\mathrm{S}$ were found around the textile industry, and the $\mathrm{P}$ around the glass industry. The $\mathrm{Cu}, \mathrm{Pb}$ and $\mathrm{Cr}$ were the dominant heavy metal found in soil around dyeing, glass and textile industry, respectively, and the study showed that the concentration of $\mathrm{Cd}$ was low in all the industrial area. The $\mathrm{CD}$ value indicated that low to consideration level of soil contamination by heavy metals. Therefore, to maintain the soil quality and reduce the heavy metal pollution in the study area the listed measures are needed to be taken: (i) Industrial units must install and regularly operate Effluent Treatment Plant (ETP); (ii) Industries should maintain the standard level mentioned on Guide for Assessment of Effluent Treatment Plant, 2008 before discharging of effluents; (iii) Environment Conservation Act, 1995 should be imposed strictly and proper monitoring should be conducted by the Government authority.

\section{Acknowledgement}

Authors are grateful to Mr. TarikulAlam, Assistant Scientific Officer, Soil Science Division, Bangladesh Institute of Nuclear Agriculture (BINA), Mymensingh, Bangladesh, for his kind cooperation and laboratory support during the research work.

\section{References}

Adegoke, J.A.;Owoyokun,T.O. and Amore,I.O. 2009. Open dumping: An analysis of heavy metals concentration of an old lead battery dumpsite. The Pacific Journal of Science and Technology, 10(2): 592-595.
Agarwal, P. and Varshney, S. 2014. Health and environmental impacts of glass industry (A case study of Firozabad Glass Industry). European Academic Research, 2(8): 10127-10149.

Ahdy, H.H.H. and Khaled,A.2009. Heavy metals contamination in sediments of the western part of Egyptian Mediterranean Sea. Australian Journal of Basic and Applied Sciences, 3: 3330-3336.

Ayres, R.S. and Westcot, D.W. 1994. Water Quality for Agriculture FAO Irrigation and Drainage Paper 29 Rev 1. Rome, Italy: Food and Agriculture Organization.

BARC (Bangladesh Agricultural Research Council). 1997. Fertilizer recommendation guide. BARC Publications. Farmgate, Dhaka. Bangladesh. 196 pages.

BBS (Bangladesh Bureau of Statistics). 2013. District Statistics 2011 Tangail. Statistics and Informatics Division, Ministry of Planning, Bangladesh. 61 p.

Bharti, P.K.; Kumar, P. and Singh, V. 2013. Impact of industrial effluents on ground water and soil quality in the vicinity of industrial area of Panipath city, India. Journal of Applied and Natural Science, 5(1): 132-136.

Biswas, T.D. and Mukherjee, S.K. 1997. Textbook of Soil Science, Tata McGraw-Hill Publishing Limited.

Black, C.A. 1965. Methods of Soil Analysis: Part 2, American Soceity for Agronmy. Inc. Madi, Wis., USA, $67 \mathrm{p}$.

Chiroma, T.M.;Ebewele, R.O. and Hymore,F.K. 2014. Comparative assessment of heavy metal level in soil, vegetables and urban grey waste water used for irrigation in Yola and Kano. International Referred Journal of Engineering and Sciences, 3(2): 1-9. 
Dahmani-Muller, H.; Van,F. and Balance,M. 2001. Metal extraction by Arabidopsis halleri grown on an unpolluted soil with amended with various metal bearing solids: A pot experiment. Environment pollution, 114: 77-84.

ElBahi, S.M.; Sroor, A.T.; Arhoma, N.F. and Darwish, S.M. 2013. XRF analysis of heavy metals for surface soil of Qarunlake and Wadi El Rayan in Faiyum, Egypt. Open Journal of Metal, 3: 21-25.

Gheorghe, I.F. and Ion, B. 2012. The effects of air pollutants on vegetation and the role of vegetation in reducing atmospheric pollution. In: Impact of air pollution on health, economy, environment and agricultural sources, ISBN: 978-953-307-528-0.

Hakanson, L. 1980. Ecological risk index for aquatic pollution control: A Sedimentological approach. Water Research, 14(8): 975-1001.

Hoganas.2013. Thermal Surfacing Glass Mould Industry Solutions. $1 \mathrm{p}$.

IFC (International Finance Corporation). 2007. Environmental, health, and safety guidelines for glass manufacturing. World Bank Group. 5 p.

Iqbal, M.A.; Chaudhary, M.N.;Zaib, S.; Imran, M.; Ali,K. and Iqbal, A. 2011. Accumulation of heavy metals $(\mathrm{Ni}, \mathrm{Cu}, \mathrm{Cd}, \mathrm{Cr}, \mathrm{Pb})$ in agricultural soils and spring irrigated by industrial waste water for seasonal plants. Journal of Environmental Technology and Management, 2(1): 1-9.

Islam, M.S.; Tusher, T.R.; Mustafa, M. and Mamun, S.A. 2012. Investigation of soil quality and heavy metal concentrations from a waste dumping site of Konabari industrial area at Gazipur in Bangladesh. IOSR Journal of Environmental Science, Toxicology and Food Technology, 2(1): 01-07.

Jackson, M.L. 1973. Soil chemical analysis. Oaretic Hall of India Private Ltd., New Delhi, India. 4647, 183 pages.

Jolly, Y.N.; Islam, A. and Mustafa, A.I. 2012. Impact of dyeing industry effluent on soil and crop. Universal Journal of Environmental Research and Technology, 2(6): 560-568.

Joshi, V.J. and Santani, D.D. 2012. Physicochemical characterization and heavy metal concentration in effluent of textile industry. Universal Journal of Environmental Research and Technology, 2(2): 93-96.

Kanan, A.H.; Marine, S.S.; Raihan, F.; Redowan, M. and Miah, M.D. 2014. Textile effluents physiochemical parameters of water and soil: Threat for agriculture. African journal of Agronomy, 2(10): 129-223.
Kanta, A.H.; Samshad, S.Z.K.M. and Hoque, S. 2014. Soil pollution in the agro-industrial areas of the northern part of Dhaka city. National University Journal of Science, 1(2): 75-84.

Khan, H.R. 2006. Assessment of SPWAC (Soil-PlantWater-Air-Contiuum) quality within and around Dhaka City. Report submitted to the director of the centre for Advanced Studies and Research in Biotechnological sciences, University of Dhaka, Bangladesh.

McGrath, S.P.; Chaudri, A.M. and Gille, K.E. 2005. Long term effect of metals in sewage sludge on soil microorganisms and plants. Journal of Industrial Microbiology, 14: 94-104.

McLaren, R.G.; Swift, R.S. and Quin, B.F. 1984. EDTA extractable copper, zinc and manganese in soils of the Chaterburt plain. New Zealand Journal of Agricultural Research, 27: 210-217.

Mido, Y. and Satake, M. 2003. Chemicals in the environment. In: Sethi, M.S. and Iqbal, S.A. (Editors). Toxic Metals. Discovery Publishing House, New Delhi. 45 ï 68 pages.

Nidhi, J. and Ashwini, K. 2011. Physicochemical analysis of soil and industrial effluents of Sanganer region of Jaipur, Rajasthan. Research Journal of Agricultural Sciences, 2(2):354-356.

Nuruzzaman, M.; Islam, M.H.; Ullah, A.; Rashid, S.M. and Gerzabek, M.H. 1998. Contamination of soil environment by the tannery industries. Bangladesh Journal of Soil Science, 25:1-10.

Page, A.L.; Miller, R.H. and Kenny, D.R. 1989. Methods of soil analysis: Part II. $2^{\text {nd }}$ Edition, American Society of Agronomy Inc., Wisconsis, USA. 1203 p.

Piper, C.S. 1950. Soil and plant analysis. Adelaide University Hassel Press, Australia. 78 pages.

Rahman, S.H.; Khanam, D.; Adyel, T.M.;Ahsan M.A. and Akbor, M.A. 2012. Assessment of heavy metal contamination of agricultural soil around Dhaka Export Processing Zone (DEPZ), Bangladesh: Implication of Seasonal Variation and Indices. Applied Sciences, 2: 584-601.

Sharma, R. and Raju, N.S. 2013. Correlation of heavy metal contamination with soil properties of industrial areas of Mysore, Karnataka, India by cluster analysis. International Research Journal of Environment Sciences, 2(10): 22-27.

Shivakumar, D.; Srikantaswamy, S.; Kiran, B.M. and Sreenivasa, S. 2012. Study of impacts of industries on soil characteristics of Mysore city, India. International Journal of Geology, Earth and Environmental Sciences, 2(2): 25-33. 
Shivkumar, D. and Srikantaswamy, S. 2012. Study of physicochemical characteristics of Industrial zone soil -A case study of Mysore city, Karnataka, India. International Journal of Environmental Science, 3(1): 224-232.

Sonawane, D.V.; Lawande, S.P.; Gaikwad, V.B. and Kuchekar, S.R. 2012. Impact of industrial waste water on soil quality and organic matter around Kurkumb industrial area, Daund, Pune District. International Journal of Chemical Sciences, 8(1): 97-102.

SRDI (Soil Resources Development Institute). 2001. Land and Soil Resources Utilizations Guide (in Bengali). Upazila Nirdeshika Series- Singra Upazila, Soil Resources Development Institute, Dhaka.22-55 pages.

Tomlinson, D.L.; Wilson, J.G.;Harris,C.R. and Jeffrey,D.W. 1980. Problems in the assessment of heavy metal levels in estuaries and the formation of a pollution index. Helgoländer Meeresuntersuchungen, 33(1-4): 566-575.
Tu, C.; Zheng, C.R. and Chen, H.M. 2000. Current status of the soil-plant system in a copper Gangue area. Acta Pedol Sin, 37: 284-287.

Turekian, K.K. and Wedepohl, K.H. 1961. Distribution of the elements in some major units of the earthôs crust. Geological Society of America Bulletin, 72: 175-192.

Vandana, N.N.; Murthya, P. and Saxena,P.R.2011. Assessment of heavy metal contamination in soil around hazardous waste disposal sites in Hyderabad city (India): Natural and anthropogenic implications. Environmental Research and Management, 2(1): 27-34.

Yadav, P.K.; Goyal, B.; Sharma, R.K.; Dubey, S.K. and Minhas, P.S. 2002. Post irrigation impact of domestic sewage effluent on composition of soils, crops and ground water- A case study. Environment International, 28(6): 481-486.

Zakir, H.M.; Sumi, S.A.; Mohiuddin, K.M. and Kaysar,S. 2015. Heavy metal contamination in surface soils of some industrial areas of Gazipur, Bangladesh. Journal of Chemical, Biological and Physical Sciences, 5(2): 2191-2206. 